\title{
PERKAWINAN ADAT MAMASA STUDI ADMINISTRASI KEPENDUDUKAN ANAK DILUAR NIKAH (PERDA KABUPATEN MAMASA NOMOR 5 TAHUN 2017)
}

\section{Mamasa Traditional Marriage: A Study of Population Administration of Children Born Out of Wedlock (Regional Regulation of Mamasa Regency Number 5 in 2017)}

\author{
Yustianto $^{1}$, Syamsul Bahri ${ }^{2}$, Juharni $^{2}$ \\ ${ }^{1}$ Pemerintahan Daerah Kabupaten Mamasa, Sulawesi Barat \\ ${ }^{2}$ Program Studi Ilmu Administrasi Negara, Program Pascasarjana, Universitas Bosowa \\ Email: yustianto.tallulembang@gmail.com
}

Diterima: 21 Juli 2020

Dipublikasikan: 07 Desember 2020

\begin{abstract}
ABSTRAK
Penelitian ini dilakukan di Dinas Kependudukan dan Pencatatan Sipil Kabupaten Mamasa yang dilaksanakan pada bulan April-Mei 2020. Pendekatan dalam penelitian ini menggunakan deskriptif kualitatif berdasarkan fenomenologi yang terjadi. Teknik pengumpulan data melalui observasi, wawancara mendalam, dan studi kepustakaan. Tujuan dari penelitian ini adalah: (1) Untuk mengetahui mekanisme perkawinan adat Mamasa untuk anak lahir diluar nikah; (2) Untuk mengetahui peran adat Mamasa dalam pembuatan akta lahir bagi anak diluar nikah; dan (3) Untuk mengetahui dampak social yang ditimbulkan dari perkawinan anak diluar nikah. Hasil penelitian menunjukkan bahwa: (1) Mekanisme perkawinan adat Mamasa untuk anak diluar nikah dilakukan melalui sebuah ritual adat sebagai suatu tradisi adat yang dalam istilah masyarakat adat Mamasa disebut dengan istilah dipa'arrangi tangngana langi yang berarti diangkat kembali martabatnya. Pihak keluarga ayah anak diluar nikah tersebut mendatangi pihak keluarga ibu dari anak tersebut untuk memberikan pengakuan bahwa anak tersebut memiliki ayah biologis yang siap bertanggungjawab layaknya sebagai seorang ayah; (2) Peran adat Mamasa dalam pembuatan akta lahir anak diluar nikah selama ini belum dilakukan sebagai mana semestinya yang diatur di dalam Perda Nomor 5 Tahun 2017. Pembuatan akta lahir anak diluar nikah di Dukcapil Mamasa murni merupakan kebijakan dari Dukcapil dimana surat keterangan yang bertanda didalamnya bukan Lembaga Adat sebagaimana seharusnya: dan (3) Dampak sosial perkawinan adat Mamasa terhadap anak diluar nikah adalah memberikan pengakuan kepada kedudukan seorang anak dalam keluarga dan lingkungan sosialnya. Selain itu pihak keluarga perempuan sebagai korban juga diangkat kembali martabatnya. Namun ada dampak negatif dengan adanya perkawinan adat dimana dapat menjadi preseden buruk bagi lingkungan masyarakat adat. Hal ini disebabkan para pelaku tidak diberi sanksi adat yang dapat memberi efek jerah.
\end{abstract}

Kata Kunci : Anak Luar Nikah, Pernikahan Adat, Dampak Sosial, Mamasa

\begin{abstract}
This research was conducted at the Population and Civil Registry Office of Mamasa Regency which was conducted in April-May 2020. The approach in this study was a qualitative descriptive based on the phenomenology that occurred. The data were collected through observation, in-depth interviews, and literature study. The objectives of this study are: (1) To find out the relationship between mamasa traditional marriage and children born out of wedlock; (2) To understand the role of Mamasa culture in making birth certificates for children born out of wedlock; and (3) To find out the social impacts arising from the marriage of children born out of wedlock. The results of the study show that: (1) The mechanism of Mamasa traditional marriage for children born out of wedlock is carried out through traditional rituals as a tradition, which in terms of Mamasa indigenous people is called 'dipa'arrangi tangangana langi' which means 'reappointed in dignity'. The family of the father of the child born out of wedlock goes to the family of the mother of this child to acknowledge that the child has a biological father who is ready to take responsibility as a father; (2) The role of Mamasa tradition in making birth certificates for children born out of wedlock so far has not been carried out as the regulation in Perda Number 5 in 2017. The making of birth certificates for children born out of wedlock in Mamasa Dukcapil is not an approved Customary Institution: and (3) the social impact of Mamasa traditional marriage to children born out of wedlock gives recognition of the position of the children in the family and social environment. In addition, the mothers' families also received back their dignity. However, there are negative impacts of the existence of traditional marriages which can set a bad precedent for the environment of indigenous peoples. This is because the perpetrators are not given customary sanctions which can have a lucrative effect.
\end{abstract}

Keywords: Children Born out of Wedlock, Traditional Marriage, Social Impact, Mamasa

\section{PENDAHULUAN}

Setiap anak yang lahir berhak untuk dicatatkan namanya dalam akta pencatatan sipil. Hal tersebut dijamin oleh konstitusi UUD 1945 yang kemudian dituangkan dalam peraturan perundang-undangan melalui UU Nomor
23 Tahun 2006 sebagaimana telah diubah melalui UU Nomor 24 Tahun 2013 Tentang Administrasi Kependudukan dan UU Nomor 1 Tahun 1974 sebagaimana telah diubah melalui UU Nomor 16 Tahun 2019 Tentang Perkawinan. 
Menurut Imam Sudiyat (2000) sutau perkawinan adat mempunyai akibat hukum bagi masyarakat yang bersangkutan dengan perkawinan adat tersebut. Akibat hukum tersebut telah ada mulai ketika proses pelamaran dalam proses perkawinan adat dilakukan. Setelah proses pelamaran tersebut antara orang tua dan kerabat kedua calon telah memiliki hubungan kekerabatan satu sama lain. Karena itulah dalam hukum perkawinan adat suatu perkawinan merupakan urusan kerabat dan keluarga yang berkaitan dengan martabat dan harga diri untuk mencirikan keluarga tersebut (Achyar et. al , 2019).

Tujuan dari pencatatan kelahiran seorang anak adalah untuk memberikan perlindungan hak kepada anak dan juga kepada upaya untuk membantu pemerintah dalam mewujudkan tujuan negara. Kepentingan negara melalui pemerintah adalah untuk mempermudah pemerintah mengetahui jumlah penduduk dalam negaranya yang kemudian dijadikan acuan dalam membuat kebijakan-kebijakan negara. Sementara itu pentingnya pencatatan kelahiran bagi seorang anak adalah untuk memberikan kepastian hukum bagi anak tersebut dalam lingkungan sosialnya.

Selain itu, hak untuk memiliki akta kelahiran adalah hak setiap warga negara untuk mendapatkan pelayanan sebagai bukti kehadiran pemerintah termasuk bagi anak yang lahir diluar nikah. Pengakuan akan kehadiran dirinya menjadi sangat penting dalam kehidupan bermasyarakat sehingga tidak rentan terhadap perlakuan diskriminasi dan persepsi yang buruk terhadap dirinya. Namun ada perbedaan pencatatan kependudukan bagi seoarang anak yang lahir diluar nikah atau lahir dari perkawinan tidak sah.

Menurut S. J. Andreae (1951), kata akta berasal dari bahasa Latin acta yang berarti geschrift atau surat. Sementara dalam pandangan R. Subekti dan Tjitrosoedibio (1980), bahwa kata acta merupakan bentuk jamak dari kata actum yang berasal dari bahasa Latin yang berarti perbuatan-perbuatan.

Menurut A. Pitlo (1979) akta adalah suatu bukti dalam bentuk surat yang ditandatangani yang dapat digunakan oleh seseorang untuk keperluan sesuai dengan maksud tujuan surat itu dibuat. Akta adalah surat yang memuat suatu peristiwa yang didalamnya diberikan tandatangan dengan sengaja untuk menjadi pembuktian sehingga menjadi dasar dalam membuat suatu perikatan. Adapun syarat yang ahrus dipenuhi dalam suatu surat tersebut adalah sebagai berikut: (1) Surat Itu Harus Ditandatangani; (2) Surat Itu Harus Memuat Peristiwa; (3) Surat Itu Diturunkan Sebagai Alat Bukti. Salah satu bagian dari akta adalah pencatatan kelahiran seorang anak. Menurut Maidin Gultom (2014), pencatatan kelahiran anak merupakan memberikan upaya perlindungan hak kepada seorang anak berdasarkan hukum sebagai bentuk pemberian keadilan kepada anak tersebut. Melalui akta kelahiran seorang anak dapat dibuktikan jati dirinya sebagai suatu identitas yang melekat pada dirinya sehubungan dengan hak waris, urusan asuransi dan urusan administrative lainnya seperti pengurusan KTP, KK, SIM, Paspor, perizinan, perkawinan dan lain-lain.

Fenomena yang terjadi di Mamasa, bahwa banyak anak yang lahir dari perkawinan yang tidak sah. Sehingga mereka tidak dapat membuat akta kelahiran karena anak yang dimaksud adalah anak yang lahir dari perkawinan orang tua diluar nikah (anak tidak sah). Sementara persyaratan untuk membuat akta kelahiran sesuai dengan UU administrasi kependudukan adalah harus dari perkawinan yang sah yang pembuktiannya salah satunya adalah dengan surat perkawinan yang dibuat oleh penyelenggara perkawinan atau melalui pejabat pembuat akta perkawinan.

Anak luar kawin adalah anak yang dilahirkan oleh seorang perempuan yang tidak memiliki ikatan perkawinan yang sah dengan laki-laki yang telah membenihkan anak di rahimnya, anak tersebut tidak mempunyai kedudukan yang sempurna di mata hukum seperti anak sah pada umumnya, dengan kata lain anak tersebut adalah anak yang tidak dilahirkan di dalam atau sebagai akibat suatu perkawinan yang sah (Satrio, 2001).

Berusaha untuk menjawab problematika tersebut, penelitian ini bermaksud untuk melihat seperti apa kedudukan aturan perkawinan adat Mamasa sebagaimana yang telah disebutkan didalam Perda nomor 5 Tahun 2017 tentang Pemberdayaan dan Pengembangan Lembaga Adat sehingga keberadaanya dapat didorong pada posisi yang kuat khususnya dalam administrasi kependudukan di Dukcapil kabuapeten Mamasa. Hal tersebut didasarkan atas banyaknya kasus perkawinan yang terjadi yang tidak dapat diseleseiakan menggunakan hukum posistif perkawinan karena itu harus pendekatannya adalah aturan perkawinan adat. Dampak dari persoalan tersebut membuat seorang anak yang secara administratif lahir dari perkawinan diluar nikah tidak dapat mengurus administrasi kependudukan yang salah satunya adalah akta kelahiran.

Berdasarkan data yang peneliti dapatkan dilapangan dalam pra-observasi yang peneliti lakukan di Desa Orobua Timur Kecamatan Sesenapadang Kabupeten Mamasa, pada tahun 2018 ada sekitar 7 kasus anak lahir diluar nikah yang ditangani persoalannya oleh lembaga adat Desa Orobua Timur untuk mencari solusi khususnya kepada kedudukan status dari anak yang dilahirkan tersebut (Sumber: Yohanis, anggota lembaga adat, 2019). Jumlah ini belum termasuk daerah lain yang ada di Mamasa yang juga banyak mengalami kasus yang serupa.

Fungsi dari lembaga adat dalam menangani masalah tersebut adalah memberikan pengakuan bahwa anak yang lahir diluar nikah tersebut merupakan anak hasil perkawinan kedua orang tuanya dengan menunjuk kepada ibu yang melahirkannya dan ayah yang membuat pengakuan terhadap anak tersebut. Karena itu hasilnya diharapkan dapat memberikan ruang pengakuan dan perlakuan yang sama terhadap anak tersebut dalam lingkungan sosialnya termasuk dalam mengurus administrasi kependudukan. 
Namun dalam realitanya bahwa pemberian legitimasi dari lembaga adat dengan sistem perkawinan adat tidak dapat dijadikan rujukan dalam proses pengurusan administrasi kependudukan terhadap anak yang lahir diluar nikah yang mensyaratkan bukti yang sah dari lembaga yang ditunjuk oleh pemerintah. Karena kedudukan lembaga adat merupakan bukan lembaga yang ditunjuk oleh pemerintah yang dapat menerbitkan akta suatu perkawinan maka banyak anak yang lahir diluar nikah di Mamasa tidak dapat diterbitkan akta kelahirannya. Sehingga demi untuk tertib administrasi bagi anak yang lahir diluar nikah tersebut maka pencatatan kependudukannya kemudian dilakukan dengan menggunakan nama kerabat dekat dari anak tersebut (Dok. pra-observasi dengan kepala UPTD Dukcapil Kecamatan Sesenapadang, 2019).

Dalam kondisi demikian tentu hal tersebut tidak boleh dibiarkan demi untuk memastikan pemenuhan keadilan dan hak konstitusi setiap warga negara. Karena itu diperlukan sebuah mekanisme atau sistem yang bersyarat agar tidak ada lagi warga negara yang menjadi korban. Disinilah aturan masyarakat adat menjadi penting dan diperlukan. Hal tersebut dikarenakan lembaga terkait yang ditunjuk oleh pemerintah dalam menyeleseikan masalah perkawinan anak diluar nikah tersebut tidak dapat melakukan banyak hal.

Dalam tradisi masyarakat adat Mamasa pengakuan perkawinan anak luar kawin menjadi perkawinan yang sah dikenal dengan itilah "Dipaarrangi Tangngana Langi', Kendek Sabali Lentekna". Ritual tersebut adalah sebuah bentuk acara untuk memperkenalkan atau mengumumkan kepada orang banyak bahwa perkawinan yang sebelumnya tidak sah tersebut menjadi perkawinan yang sah. Dalam ritual tersebut pihak laki-laki mendatangi pihak keluarga perempuan untuk membuat pengakuan kepada pihak keluarga perempuan, bahwa anak tersebut benar adalah darah dagingnya dan kemudian pihak keluarga perempuan bersepakat menerima pengakuan tersebut.

\section{METODE}

Penelitian ini dilaksanakan pada bulan Juni tahun 2020. Lokasi penelitian di Dinas Pencatatan Sipil Kabupaten Mamasa provinsi Sulawesi Barat. Penelitian ini menggunakan pendekatan deskriptif kualitatif terhadap fenomena sosial yang sedang terjadi. Data yang digunakan dalam penelitian ini adalah data primer dan data sekunder.

Teknik pengumpulan data dilakukan dengan metode observasi, wawancara, studi kepustakaan (Library Research), dan penelusuran data online. Teknik analisis data pada penelitian ini dilakukan secara cermat dimana data diseleksi mengggunakan teknik analisis data deskriptif yaitu data-data yang telah dihimpun dan dikumpulkan baik primer maupun sekunder, kemudian diambil kesimpulan sebagai jawaban masalah yang diteliti. Pengolahan data diakukan melalui reduksi data, penyajian data dan penarikan kesimpulan dan verifikasi data. Sementara itu kredibilitas data dalam penelitian ini dilakukan melalui perpanjangan pengamatan, meningkatkan ketekunan, triangulasi data, analisis kasus negatif, menggunakan bahan referensi, dan mengadakan member chek.

\section{HASIL DAN PEMBAHASAN}

\section{Sistem Administrasi Kependudukan Anak Diluar Nikah}

Setiap anak pada dasarnya memilki hak yang sama didalam lingkungan sosialnya. Hal tersebut dijamin oleh konstitusi UUD 1945 yang kemudian diturnkan kedalam beberapa produk peraturan perundang-undangan salah satunya adalah UU Nomor 23 Tahun 2002 tentang Perlindungan Anak. Pada Pasal 27 UU Nomor 23 Tahun 2002 Tentang Perlindungan Anak, pada ayat (1) Identitas diri setiap anak harus diberikan sejak kelahirannya kemudian pada ayat (2) Identitas sebagaimana dimaksud pada ayat (1) dituangkan dalam Akta Kelahiran. Artinya setiap anak apapun status negara melalui pemerintah harus bertanggungjawab untuk menerbitkan akta kelahirannya.

Hasil wawancara peneliti dengan Kepala Dinas Kependudukan dan Pencatatan Sipil Kabupaten Mamasa (Bapak Samuel B.) mengungkapkan bahwa:

"Proses pencatatan kepedudukan di Dukcapil Kabupaten Mamasa dilaksanakan sesuai dengan peraturan perundangan-undangan yang berlaku merujuk kepada UU Adminduk. Khusus untuk pembuatan akta kelahiran beberapa syarat yang harus dipenuhi pemohon sesui dengan UU Aminduk yaitu surat keterangan dari dokter atau bidan penolong kelahiran, nama dan identitas saksi kelahiran, KK orang tua, KTP orang tua dan kutipan akta nikah/akta perkawinan orang tua". (Wawancara, 4 Juni 2020)

Pada Dukcapil kabupaten Mamasa ada empat jenis akta kelahiran yang biasanya diterbitkan sesuai dengan kebutuhan dan kondisi dari pemohon itu sendiri. Hasil wawancara peneliti dengan Kepala Seksi Akta Kelahiran (Ibu Sampe Sandri) mengungkapkan bahwa:

"Selama ini di Dukcapil Mamasa ada empat jenis akta lahir yang biasanya kita buat sesuai dengan permintaan dari pemohon. Keempat jenis akta lahir tersebut yaitu akta lahir tanpa orang tua misalnya anak yang tidak diketahui asal usul ibu atau bapaknya, akta lahir atas nama ibu dan ayahnya, akta lahir atas nama ibunya saja dan akta lahir yang tidak dicatatkan perkawinannya". (Wawancara, 5 Juni 2020)

Sistem administrasi kependudukan untuk anak yang lahir diluar nikah khususnya dalam pembuatan akta kelahiran anak diluar nikah di Dukcapil Mamasa biasanya dibuat dalam tiga jenis. Ketiga bentuk tersebut yaitu akta lahir anak luar nikah yang dicatatkan atas nama ibunya saja, akta lahir anak luar nikah yang dicatatkan atas nama kerabatnya. Namun hal yang ketiga ini sulit untuk 
diinventarisasi karena tidak ada kerabat dari anak luar nikah tersebut yang membuat pengakuan di Dukcapil Mamasa ketika proses pengurusan. Dan, akta lahir anak luar nikah atas nama ibu dan ayahnya dengan menyertakan surat keterangan ayah sebagai ayah biologis anak tersebut.

Sementara itu untuk pembuatan akta lahir anak diluar nikah yang dicatatkan atas nama kerabatnya, salah satu kerabat korban yang tidak bersedia disebutkan nama aslinya sebut saja (Nn 1) kepada peneliti mengungkapkan bahwa:

"Waktu saya menguruskan akta lahir anak diluar nikah dari anak kerabat saya, dalam pencantuman nama orang tuanya didaftarkan atas nama kerabatnya bukan atas nama orang tua yang melahirkannya. Hal tersebut dilakukan supaya pengurusannya tidak repot dan berbelit-belit apalagi dengan kondisinya seperti ini. Dalam keluarga manapun kondisi seperti ini dipandang sebagai suatu aib dalam keluarganya". (Wawancara, 3 Juni 2020)

Banyak kasus yang terjadi dilokasi dimana penelitian ini dilakukan dimana anak yang lahir diluar kawin tidak diakui oleh ayah biologisnya sebagai anak kandung. Kalaupun ada prosesi ritual adat yang dilakukan dalam memberikan pengakuan terhadap anak tersebut, masalanya adalah lembaga adat yang bertindak sebagai penengah dan fasilitator tidak membuatkan surat keterangan atas telah dilakukannya perkawinan adat untuk anak yang lahir diluar nikah tersebut. Hal inilah yang membuat banyak orang tua atau kerabat anak sebagai korban merasa enggan dan malu ketika akan menguruskan akta lahir bagi anaknya tersebut.

Hasil wawancara peneliti dengan kerabat orang tua anak sebagai korban ( $\mathrm{Nn} \mathrm{1)} \mathrm{mengungkapkan} \mathrm{kepada}$ peneliti bahwa:

"Ketika ritual adat dilakukan untuk memberikan keterangan pengakuan kepada kami sebagai keluarga dari ayah biologisnya, lembaga adat sebagai fasilitator hanya bertindak sebatas melakukan ritual. Tetapi kami tidak dibuatkan dalam bentuk surat pernyataan atau surat keterangan yang memuat ibu dan ayah dari anak kerabat kami tersebut. Yang mungkin saja dapat kami gunakan dalam pengurusan pembuatan akta lahir bagi anak tersebut". (Wawancara, 3 Juni 2020)

Saat peneliti melakukan konfirmasi akan hal tersebut kepada tokoh lembaga adat Mamasa (Bapak Palullungan) mengungkapkan bahwa:

"Selama ini yang kami lakukan adalah sebatas melakukan ritual adat untuk anak yang lahir diluar nikah. Dan ini kebiasaan yang selama ini kita lakukan turun-temurun tidak lebih dari itu". (Wanwancara, 2 Juni 2020)

Pengurusan pembuatan akta lahir anak luar nikah yang didalam akta kelahiran anak tersebut dicatatkan atas nama ibu dan ayahnya di Dukcapil Mamasa dilakukan secara berbeda dengan pengurusan akta lahir pada umumnya. Dimana orang tua yang akan menguruskan akta lahir anaknya menyertakan surat keterangan bahwa anak yang dimaksud adalah dari darah dagingnya. Surat tersebut bermaterai dan dibubuhi tandatangan dari orang tua anak yang lahir diluar nikah tersebut. Saat wawancara dengan Kepala Dinas Kependudukan dan Pencatatan Sipil kabupaten Mamasa (Bapak Samuel B.) mengungkapkan bahwa:

"Selama ini jika ada orang tua yang menguruskan akta lahir bagi anaknya dimana anak tersebut lahir diluar nikah maka jika pencatatannya akan dicatatkan atas nama ibu kandung dan ayah kandung maka orang tua yang bersangkutan yaitu ayah kandungnya menyertakan surat keterangan dimana dirinya bertanda yang memuat tentang keterangan bahwa anak tersebut adalah anak dari darah dagingnya". (Wawancara, 4 Juni 2020)

Ketika peneliti mengkonfirmasi tentang syarat pembuatan akta lahir sesuai dengan yang diatur didalam UU Aminduk dimana salah satu yang dipersyaratkan adalah surat nikah orang tua. Sementara anak yang lahir diluar nikah tentu tidak memiliki akta nikah orang tua sesuai dengan yang dipersyaratkan tersebut. Menurut Kepala Dinas Kependudukan dan Pencatatan Sipil kabupaten Mamasa (Bapak Samuel B.) mengungkapakan kepada peneliti bahwa:

"Pembuatan akta lahir anak diluar nikah ini sudah syarat sesuai dengan UU karena Dukcapil juga berdasar kepada rugalasi peraturan perundangundangan yang berlaku. Anak yang lahir diluar nikah memiliki hak yang sama dengan anak lain pada umumnya. Dan Dukcapil Mamasa harus memastikan perlindungan terhadap setiap hak-hak anak tersebut". (Wawancara, 4 Juni 2020)

Ketika peneliti melakukan konfirmasi apakah selama ini Dukcapil Mamasa perna menerbitkan akta lahir anak diluar nikah berdasar kepada surat keterangan yang dibuat oleh lembaga adat sebagai pihak yang selama ini bertugas dalam urusan perkawinan adat bagi orang tua anak yang lahir diluar nikah. Kepala Seksi Akta Kelahiran (Ibu Sampe Sandri) mengungkapkan kepada peneliti bahwa:

"Selama ini yang kita lakukan adalah bekerjasama dengan kepala Desa setempat khususnya ketika mengkonfirmasi tentang status perkawinan adat bagi orang tua anak yang lahir diluar nikah tersebut. Selain karena kepala Desa adalah orang yang bertaggungjawab bagi masyarakatnya di Desa juga karena biasanya kepala Desa sudah bagian dari tokoh masyarakat yang tahu persis dengan segala yang terjadi di Desanya". (Wawancara, 5 Juni 2020)

Selanjutnya adalah peneliti melakukan konfirmasi kepada Ketua Lembaga Adat Kabupaten Mamasa (Bapak Dessa) berkaitan dengan apakah lembaga adat perna terlibat dalam urusan pembuatan akta lahir bagi anak yang lahir diluar nikah seperti yang pada umumnya diurus perkawinan adatnya oleh lembaga adat. Dalam keterangannya kepada peneliti mengungkapkan bahwa:

"Selama ini kita tidak perna terlibat dalam urusanurusan seperti itu. Tugas kita adalah memastikan 
jika ada masalah seperti itu tidak menimbulkan masalah lainnya dalam masyarakat". (Wawancara, 1 Juni 2020)

Berdasarkan Perda Nomor 5 Tahun 2017 tentang Pemberdayaan dan Pegembangan Lembaga Adat Kabupaten Mamasa pada Pasal 7 disebutkan bahwa:

"Maksud dilakukan Pemberdayaan dan Pengembangan Lembaga Adat adalah untuk meningkatkan peranan nilai-nilai adat istiadat, kebiasaan-kebiasaan masyarakat dan Lembaga adat dalam menunjang kelancaran penyelenggaraan pemerintahan, kelangsungan pembangunan dan peningkatan ketahanan nasional serta turut serta mendorong mensejahterakan warga masyarakat setempat". (Arsip Pemkab Mamasa, 2020)

Saat melakukan konfirmasi kepaada ketua DPRD Kkabupaten Mamasa (Bapak Orsan Soleman Bongga) sebagai pihak yang terlibat secara langsung dalam perumusan dan persetujuan Perda Nomor 5 Tahun 2017 kabupaten Mamasa, kaitannya dengan semangat yang mendasari Perda tersebut dibuat mengungkapkan kepada peneliti bahwa:

"Perda Nomor 5 Tahun 2017 tentang Pemberdayaan dan Pengembangan Lembaga Adat yang kita buat dan sepakati saat itu semangatnya adalah bagaimana melestarikan budaya dengan segala kearifan lokal yang ada di Mamasa sehingga dapat memberikan kontribusi agenda-agenda pembangunan yang ada di Mamasa yang sedang dikerjakan. Lembaga adat mempunyai peran seperti itu dan ini yang ingin kita dorong secara terus menerus". (Wawancara, 6 Juni 2020)

Pada tahun 2018 telah dilakukan kerjasama antara pemerintah dalam hal Dukcapil Mamasa dengan Lembaga Adat Mamasa bersama dengan Pemuka Agama khususnya agama Nasrani dalam hal ini Badan Pekerja Majelis Sinode Gereja Toraja Mamasa (BPMS GTM) kaitannya dengan sinkronisasi kemitraan masing-masing lembaga berkaitan dengan segala jenis perkawinan yang dilakukan diwilayah kabupaten Mamasa. Kerja sama tersebut ditindaklanjuti dengan pembuatan nota kesepahaman dalam bentuk Memorandum of Understanding (MoU) antar lembaga. Menurut Kepala Seksi Akta Kelahiran (Ibu Sampe Sandri) kepada peneliti mengungkapkan bahwa:

"Perna dilakukan kerjasama dalam bentuk pembuatan MoU antara Dukcapil, Lembaga Adat dengan BPMS GTM pada tahun 2018. Kerjasama tersebut berkaitan dengan sinkronisasi kegiatan kelembagaan dalam urusan-urusan perkawinan dilingkup wilayah kabupaten Mamasa terkhusus kepada perkawinan-perkawinan adat. Tujuannya supaya urusan-urusan di Dinas Dukcapil Mamasa juga mudah diseleseikan khususnya yang ada kaitannya dengan perkawinan-perkawinan adat". (Wawancara, 5 Juni 2020)

Berkaitan dengan $\mathrm{MoU}$ tersebut ternyata tidak sampai dipahami pada kegiatan administratif di Dukcapil Mamasa. Lembaga adat hanya dalam posisi untuk mendukung kegiatan-kegiata perkawinan yang ada hubungannya dengan upaya memperlancar kegiatan penyelenggaraan pemerintahan melalui Dukcapil Mamasa.

Karena selama ini pemenuhan persyaratan pembuatan akta lahir anak luar nikah tidak berasal dari lembaga adat maka di Dukcapil Mamasa cukup dengan syarat surat keterangan dari ayah dari anak tersebut. Hasil wawancara dengan Kepala Dinas Dukcapil Mamasa (Bapak Samuel B.) mengungkapkan kepada peneliti bahwa:

"Pembuatan akta lahir di Dukcapil Mamasa untuk anak luar nikah cukup denga surat keterangan dari ayah anak tersebut bahwa dia adalah ayah biologis dari anak tersebut". (Wawancara, 4 Juni 2020)

Mekanisme Perkawinan Adat Mamasa Untuk Anak diluar Nikah

Dalam tradisi perkawinan adat Mamasa, kegiatan perkawinan adat tidak hanya untuk perkawinan yang dilakukan melalui proses pelamaran. Tetapi ada juga perkawinan adat yang dilakukan oleh masyarakat adat tanpa melalui proses pelamaran yaitu perkawinan adat untuk anak yang lahir diluar nikah.

Dikalangan masyarakat adat Mamasa, anak luar kawin dianggap sebagi aib dalam keluarga, sehingga mereka menjadi tersisikan dalam lingkungan sosialnya. Karena itu, dalam tradisi kebiasaan masyarakat adat Mamasa mereka memiliki tradisi perkawinan adat untuk anak yang lahir diluar nikah. Tradisi tersebut dikenal dengan istilah dipa'arrangngi tanggana langi' yang pada pokoknya adalah untuk menyampaikan kepada masyarakat umum bahwa anak yang lahir tersebut memiliki ayah biologisnya yaitu seorang laki-laki yang mengakui bahwa dialah ayah dari anak yang lahir tersebut.

Saat peneliti melakukan wawancara dengan tokoh masyarakat adat Mamasa (Bapak Deppagoga') mengungkapkan bahwa:

"Dalam tradisi perkawinan adat Mamasa, kita memiliki kebiasaan menyeleseikan kasus-kasus anak yang lahir diluar perkawinan yang sah. Ritual tersebut disebut dengan istilah dipa'arranggi tangngana langi'. Dimana keluarga dari ayah anak tersebut datang membuat pengakuan bahwa anak tersebut memiliki ayah biologisnya ketika sudah lahir. Ritual dipa'arrangi tangngana langi' biasanya dilakukan sebelum anak tersebut lahir". (Wawancara, 2 Juni 2020)

Pada saat ritual tersebut dilakukan, tokoh-tokoh masyarakat adat melalui lembaga adat menjadi fasilitator ritual pertemuan. Hadir juga perwakilan keluarga pihak perempuan untuk menunggu tamu dari pihak laki-laki. Dalam wawancara yang peneliti lakukan dengan tokok masyarakat adat Mamasa (Bapak Deppagoga') mengungkapkan bahwa:

"Tokoh-tokoh masyarakat melalui lembaga adat bertanggungjawab atas urusan-urusan seperti itu, 
karena ini menyangkut nama baik keluarga besar dari anak dan perempuan tersebut. Kegiatan yang kita lakukan adalah menjadi fasilitator untuk mempertemukan dua keluarga yang bersangkutan. Termasuk memberikan desakan kepada pihak lakilaki sebagai ayah dari anak tersebut agar bertanggungjawab atas kelahiran anak tersebut secara adat". (Wawancara, 2 Juni 2020)

Desakan lembaga adat meminta pertanggungjawaban dari pihak laki-laki adalah suatu keharusan yang harus dilakukan oleh mereka yang berbuat. Dan cara tersebut dianggap paling baik dalam rangka untuk menghindari hal-hal yang tidak diinginkan, dalam istilah masayarakat adat Mamasa disebut dengan istilah ussampun mataran atau mencegah pertengkaran seperti pertumpahan darah.

Ketika ritual tersebut berlangsung, perwakilan keluarga dari pihak laki-laki menyampaikan maksud kedatangannya. Dimana pada pokoknya adalah datang menyampaikan pengakuan bahwa anak yang sedang dikandung dan akan segera lahir tersebut adalah memiliki ayah kandung yang akan bertanggungjawab penuh sebagai ayah biologisnya. Hanya saja ayah dari anak tersebut tidak dapat menikahi ibu dari anak yang dimaksud. Dalam tradisi masyarakat adat Mamasa disebut dengan istilah kende' sabali lentekna artinya datang hanya untuk anaknya bukan untuk menikahi ibunya.

Ketika peneliti mengkonfirmasi kenapa sehingga tidak sampai menikahkan secara sah kedua orang tersebut, tokoh masyarakat adat Mamasa (Bapak Deppagoga') menyampaikan bahwa:

"Saya kira belum perna terjadi kasus seperti itu sampai dinikahkan. Karena kalau bisa dinikahkan tentu ritualnya bukan seperti ini tetapi dilakukan sesuai dengan tradisi perkawinan adat secara umum yang biasa dilakukan karena keadaannya dianggap normal. Berbeda dengan kasus anak lahir diluar nikah, dimana kasus ini bukan kasus biasa melainkan kasus tidak biasa. Dimana pelaku yaitu ayah dari anak tersebut terikat perkawinan yang sah dengan istrinya, sekalipun ibu dari anak yang dimaksud masih gadis atau belum perna bersuami. Atau ibu dari anak tersebut terikat perkawinan dan atau keduanya masih terikat perkawinan dengan suami atau istrinya yang sah. Kalau kita paksakan untuk dinikahkan maka akibatnya adalah urusan hukum, dan bukan hanya para pelaku yang bisa dituntut tetapi juga kita yang bertindak sebagai penengah atau fasilitator".(Wawancara, 2 Juni 2020)

Sementara itu biaya yang digunakan selama proses ritual tersebut berlangsung ditanggung penuh oleh pihak laki-laki. Bahkan juga sudah diambil pemufakatan bersama dimana anak yang lahir tersebut merupakan tanggungan dari ayahnya mulai dari sejak kelahirannya termasuk biaya pertumbuhan anak, biaya sekolah dan biaya-biaya lain.

Seberapun besarnya biaya yang digunakan selama ritual tersebut dilakukan wajib hukumnya bagi pihak laki- laki untuk memenuhinya. Bahkan biasanya yang terjadi pihak keluarga perempuan sebelumnya telah mengambil kebutuhan ritual tanpa harus member tahu terlebih dahulu kepada pihak laki-laki. Sebagai bentuk tanggungjawab laki-laki maka tidak alasan untuk tidak memenuhinya.

Dampak Sosial Perkawinan Adat Mamasa terhadap Anak diluar Nikah

Tradisi penyeleseian masalah anak diluar nikah adalah semata-mata tujuannya untuk memberikan perlindungann kepada korban dan seluruh kerabatnya sekaligus perlindungan kepada anak yang lahir diluar ikah tersebut. Dalam masyarakat Mamasa anak yang lahir diluar nikah adalah suatu aib keluarga. Dalam rangka untuk mengurangi rasa maluh tersebut jika pihak keluarga laki-laki atau ayah biologis dari anak tersebut membuat suatu pengakuan yang dilakukan melalaui ritual tradisi adat. Hasil wawancara peneliti dengan Ketua Lembaga Adat Mamasa (Bapak Dessa) mengungkapkan kepada peneliti bahwa:

"Anak yang lahir diluar nikah adalah suatu aib dalam tradisi masyarakat adat Mamasa. Dan bukan hanya kepada para korban tetapi juga kepada seluruh kerabat dekat dari korban tersebut. Semua merasa malu dan telah kehilangan martabat dan harga diri keluarganya. Karena itu dalam tradisi adat Mamasa ada upaya yang dilakukan sehingga setidaknya dapat mengurangi rasa malu tersebut. Ini bagian daripada perlindungan kepada setiap korban bersama dengan seluruh kerabatnya". (Wawancara, 1 Juni 2020)

Dalam budaya masyarakat adat Mamasa, kasuskasus kelahiran anak diluar nikah sebagai suatu aib atau pencemaran nama baik keluarga besar yang biasa diistilakan dengan melammak rokko maririnna litak yang artinya secara harafiah memasukkan kedalam tanah kuning. Jika dimaknai berarti pelaku yang melakukan hal tersebut sudah tidak lagi menghargai dan menganggap kehadiran rumpun keluarga besarnya sehingga dipersepsikan sebagai tanah kuning yaitu tanah yang tidak berarti karena tidak dapat ditumbuhi tanaman apapun.

Hal inilah yang membuat kerabat keluarga pihak perempuan merasa geram da dipenuhi kemarahan apalagi ketika ayah bilogis dari anak yang lahir tersebut tidak bersedia bertanggungjawab. Bentuk pertanggungjawaban ayah dari anak tersebut tidak harus dalam bentuk untuk menikahi ibu dari anak tersebut tetapi cukup dengan pengakuannya didepan tokoh masyarakat adat dan keluarga kerabat perempuan bahwa dia adalah ayah bilogis dari anak yang lahir tersebut.

Dalam rangka untuk menghindari hal-hal yang tidak diinginkan terjadi dalam masyarakat adat Mamasa maka kegiatan ritual perkawinan adat anak diluar nikah ini adalah upaya untuk meredam kemarahan dan kegeraman kerabat keluarga pihak perempuan. Dalam istilah masyarakat adat Mamasa disebut dengan istilah ussampun mataran secara harafia berarti menutup besi tajam. Jika dimaknai berarti untuk menghindari peperangan atau pertumpahan darah. 
Hasil wawancara peneliti dengan tokoh masyarakat adat Mamasa (Bapak Palullungan) mengungkapkan kepada peneliti bahwa:

"Tradisi ritual perkawinan adat untuk anak luar kawin adalah tujuannya meredam konflik dalam masyarakat adat yang biasa disebut dengan istilah unsampun mataran. Rasa malu bagi kerabat korban dari perempuan tersebut adalah pemikiran utama yang lembaga adat pikirkan supaya rasa malu kerabat korban tersebut tidak seperti ketika ayah dari anak tersebut belum membuat pengakuan". (Wawancara, 2 Juni 2020)

Ketika ritual perkawinan adat untuk anak yang lahir diluar nikah tersebut telah dilakukan maka secara tidak langsung membersikan segala keburukan dari perbuatan tersebut. Atau dapat dimaknai secara sederhana bahwa anak yang lahir tersebut bukan lagi anak luar kawin tetapi anak yang sah dari kedua orang tuanya dan perkawinannya dilakukan secara adat. Hanya saja kedua orang tuanya tidak dapat terikat ikatan rumah atngga sebagai suami dan istri.

Melalui ritual tersebut menjadi pengakuan secara tersirat kepada masyarakat umum (masyarakat adat) bahwa anak yang telah lahir tersebut adalah anak dari seorang ayah telah dinikahkan secara adat kedua orang tuanya sehingga anak tersebut bukan lagi anak yang lahir tanpa ayah. Hal inilah yang kemudian melahirkan pengakuan dan respon secara baik oleh seluruh masyarakat adat kepada anak tersebut

Hasil wawancara peneliti dengan tokoh masyarakat adat (Bapak Deppagoga) kepada peneliti mengungkapakan bahwa:

"Setelah ritual perkawinan ini dilakukan berarti anak tersebut bukan lagi anak haram atau nak luar kawin tetapi sudah menjadi anak yang sah kedua orang tuanya. Masyarakat adat juga akan dengan sendirinya mengetahui hal tersebut sehingga dengan sendirinya pula akan memberikan pengakuan terhadap anak tersebut. Jadi kedua orang tuanya sudah sah menjadi orang tua kandung dari anak tersebut, karena itu urusan nafkah dan biaya-biaya lain anaknya sudah menjadi tanggungjawab kedua orang tuanya". (Wawancara, 2 Juni 2020)

Pengakuan inilah yang secara tidak langsung memberi perlindungan terhadap hak-hak seorang anak. Perlindungan terhadap pertumbuhannya, perlindungan pendidikannya, dan perlindungan-perlindungan lainnya sebagai hak seorang anak menjadi tanggung ajwab kedua orang tuanya. Proses penafkahan tersebut telah dibicarkan dan disepakati pada saat ritual tersebut dilakukan bersama dengan kerabat keluarga ayah dari anak tersebut. Bahwa ayahnya sebagai orang tua kandungnya wajib hukumnya untuk membiayai seluruh keperluan anaknya sesuai degan kemampuannya.

Sistem Administrasi Kependudukan Anak diluar Nikah

Pelayanan publik yang telah ditunjukkan oleh Dukcapil Mamasa dalam hal urusan administrasi kependudukan sudah dilakukan dengan baik yaitu memberikan kepuasan dan kemanfaatan (Paiman Napitupulu; 2007, Mulyadi; 2016). Hal tersebut dapat dilihat dalam upaya yang diberikan melalui kebijakankebijakan oleh Dukcapil Mamasa terhadap segala jenis urusan kependudukan termasuk yang berkaitan dengan pencatatan sipil anak yang lahir diluar nikah.

Secara administratif yang diatur didalam UU Nomor 1 Tahun 1974 tentang Perkawinan bahwa syarat seseorang dicatatkan nama ayah dan nama ibu dalam akta lahirnya adalah harus menyertakan akta nikah kedua orang tuanya. Jika aturan ini dipahami secara linear maka itu berarti anak yang lahir diluar nikah yang tentu orang tuanya tidak memiliki akta perkawinan secara tidak langsung tidak bersyarat untuk diterbitkan akta kelahirannya.

Namun ada yang berbeda dengan pencatatan akta kelahiran anak yang lahir diluar nikah, pasalnya kedua orang tuanya tidak terikat dengan pernikahan yang sah sehingga secara tidak langsung anak tersebut tidak memiliki akta pernikahan kedua orang tuanya. Sementara hak untuk dicatatkan kependudukannya oleh negara melalui pemerintah adalah hak setiap anak yang dijamin oleh UUD 1945 (lihat: UU Perlindungan Anak, Maidin Gultom; 2004).

Pencatatan akta kelahiran untuk anak yang lahir diluar nikah di Dukcapil Mamasa dilakukan dalam bentuk dicatatkan tidak atas nama ibu dan ayahnya, dicatatkan atas nama ibunya saja, dicatatkan atas nama ibu dan ayahnya atau tidak dicatatkan sama sekali. Namun ada orang tua yang mencatatkan akta lahir anaknya atas nama kerabatnya (lihat: Mertokusumo 2001)

Berkaitan dengan pencatatan akta lahir bagi anak luar nikah dimana dalam isi surat akta lahir tersebut akan dicatatkan atas nama ibu dan ayah kandungnya maka Dukcapil Mamasa terlebih dahulu meminta surat keterangan dari ayah biologis yang akan bertanggungjawab atas kelahiran anak tersebut. Surat keterangan tersebut memuat bahwa benar yang bersangkutan adalah ayah biologis dari anak yang dimaksud dan bersedia bertanggungjawab atas segala akibat hukum yang berlaku.

Dalam surat akta tersebut dibuatkan catatan kaki yang memuat tentang status dari ayah yang bertanggungajwab atas kelahiran anak tersebut. Didalam catatan kaki tersebut tersirat bahwa anak yang dibuatkan akta lahir tersebut lahir dari pernikahan luar nikah.

Proses pembuatan akta lahir untuk anak luar nikah tersebut murni adalah inisiatif dan kebijakan dari Dukcapil Mamasa. Sekalipun mereka berdalil bahwa hal tersebut sesuai dengan peraturan perundang-undangan yang berlaku, termasuk UU Nomor 23 Tahun 2006 sebagaimana telah diubah melalui UU Nomor 24 Tahun 2013 tentang Administrasi Kependudukan.

Didalam UU Aminduk tersebut tidak mengatur secara spesifik berkaitan dengan pembuatan akta lahir anak luar nikah yang didaftarkan atas nama ibu dan ayah kandungnya, yang ada adalah mengatur tentang jenis- 
jenis akta kelahiran dimana akta lahir anak dibagi menjadi empat bentuk yaitu akta lahir yang dicatatkan atas nama ibunya saja, dicatatkan atas nama ibu dan ayahnya, tidak dicatat atas nama ibu dan ayahnya dan akta lahir yang tidak dicatatkan sama sekali.

Sementara itu jika mengacuh kepada pendapat Sudikno Mertokusumo (2001) yang membagi akta kelahiran kedalam empat jenis yaitu akta kelahiran umum yaitu yang dilaporkan sebelum 60 setelah kelahiran anak, akta kelahiran istimewa yaitu yang dilaporkan setelah lewat dari 60 hari setelah kelahiran anak, akta kelahiran luar biasa yaitu akta lahir bagi mereka yang lahir di zaman revolusi dan akta kelahiran tambahan yaitu kelahiran pada tanggal 1 januari 1967 sampai dengan 31 Maret 1983.

Berkaitan dengan anak luar nikah yang akan dicatatkan akta lahirnya dengan mencantumkan nama ibu dan ayah kandungnya maka selama ini kebijakan yang dilakukan oleh Dukcapil Mamasa cukup dengan menyertakan surat keterangan yang bermaterai yang ditandatangani oleh ayah dari anak tersebut.

Jika mengacuh kepada UU Perkawinan dan putusan MK berkaitan dengan uji materi UU Perkawinan, surat keterangan yang dibuat oleh orang tua dari anak tersebut sebenarnya tidak bersyarat sesui dengan UU dan putusan MK tersebut. Dimana prasyarat pembuktiannya seharusnya atas dasar hasil uji ilmiah yaitu melalui ilmu pengetahuan dan teknologi.

Namun berbeda jika rujukan yang digunakan mengacuh kepada UU Nomor 23 Tahu 2002 tentang Perlindungan Anak dimana pada ayat (1) Identitas diri setiap anak harus diberikan sejak kelahirannya kemudian pada ayat (2) Identitas sebagaimana dimaksud pada ayat (1) dituangkan dalam Akta Kelahiran. Jadi didalam UU ini tidak membatasi hak memperoleh akta lahir tersebut kepada siapun termasuk anak yang dilahirkan diluar pernikahan yang sah.

Jadi jika alternatif yang digunakan selama ini oleh Dukcapil Mamasa dalam penerbitan akta lahir anak luar nikah yang dicatatkan atas nama ibu dan ayah kandungnya cukup dengan menggunakan syarat surat keterangan pengakuan. Hal ini berarti bahwa surat keterangan tersebut dianggap konstitusional sekalipun kebijakanya pada level pengaturan di internal Dukcapil Mamasa. Pada posisi ini sebetulnya ada kebijakan pemerintah daerah kabupaten Mamasa yang jauh lebih terlegitimasi jika dijadikan rujukan oleh Dukcapil Mamasa. Kebijakan tersebut adalah Peraturan Daerah (Perda) Kabupaten Mamasa Nomor 5 Tahun 2017 tentang Pemberdayaan dan Pengembangan Lembaga Adat.

Menggunakan rujukan Perda tentang lembaga adat sebagai prasyarat membuat akta lahir anak diluar nikah untuk dicatatkan atas nama ibu dan ayah kandungnya dianggap relevan karena menyangkut tentang lembaga adat dimana selama terlibat secara langsung dalam urusan perkawinan khususnya kepada anak yang lahir diluar nikah. Bahkan yang terlibat mengesahkan suatu perkawinan anak luar nikah adalah oleh lembaga adat itu sendiri.

Peran lembaga adat dalam mengesahkan perkawinan adat anak diluar nikah seharusnya dipersepsikan sebagai bagian penting dari upaya membantu pemerintah khususnya Dukcapil Mamasa dalam urusan pencatatan kependudukan anak diluar nikah yang bersyarat secara administratif. Sehingga urusan pencatatan anak luar nikah dapat lebih mudah dilakukan melalui pemahaman yang sama antara lembaga adat dan Dukcapil Mamasa.

Namun masalah kemudian adalah peran lembaga adat sesuai dengan yang diinstruksikan didalam Perda Nomor 5 Tahun 2017 sama sekali tidak dikerjakan. Pada hal ruang untuk melibatkan lembaga adat dalam hal urusan pembuatan akta lahir anak diluar nikah sangat besar. Pertama, Perda Nomor 5 Tahun 2017 tentang Lembaga Adat Mamasa memberi ruang untuk hal tersebut (lihat Pasal 7; Pasal 9 Ayat (3) poin (b); dan Pasal 9 ayat (5). Kedua selama ini yang digunakan oleh Dukcapil Mamasa adalah surat keterangan yang dibuat sendiri oleh orang tua yang bersangkutan jika dalam akta lahir anak tersebut ayah biologisnya akan dicatatkan namanya. Idealnya dalam hal pemberdayaan lembaga adat surat keterangan tersebut sebaiknya yang bertanda sebagai pihak yang terlibat secara langsung dalam ritual pernikahan adat untuk anak yang lahir diluar nikah tersebut adalah lembaga adat.

Namun ternyata ada mis-understanding antara pemerintah sebagai pembuat aturan dalam hal ini Perda Nomor 5 Tahun 2017 tersebut dengan Lembaga Adat dan juga Dukcapil sebagai salah satu instansi penyelenggara pemerintahan dalam hal urusan pelayan publik. Pemahaman terhadap Perda tersebut sangat lemah antar lembaga sementara disisi yang lain beberapa pasal didalam Perda tersebut masih sangat abstrak dimana belum menjabarkan apa yang dimaksud dengan tugas Lembaga Adat dalam urusan penyelenggaraaan pemerintahan. Proses penjabaran sebagai turunan dari Perda tersebut dapat dibuat dalam bentuk peraturan bupati (lihat: Permendagri 80 Tahun 2015) yang mensinkronkan proses pemberdayaan lembaga adat dengan Dukcapil dalam hal urusan perkawinan dan pencatatan sipil lainnya termasuk urusan pembuatan akta lahir anak diluar nikah.

Lembaga adat juga selama ini hanya menganggap bahwa tugas atau tofoksi mereka adalah hanya berkaitan dengan masalah budaya dan kebiasaan dalam masyarakat adat di Mamasa. Urusan-urusan dalam bentuk administratif misalnya tidak dianggap sebagai bagian dari tanggungjawab lembaga adat yang mereka harus kerjakan.

\section{Mekanisme Perkawinan Adat Mamasa untuk Anak diluar Nikah \\ Dalam perkawinan adat untuk anak yang lahir diluar nikah dilakukan dengan cara pihak laki-laki yang dianggap ayah biologis dari anak tersebut mendatangi pihak keluarga perempuan untuk membuat pengakuan bahwa dialah ayah dari anak yang dimaksud. Anak yang lahir diluar nikah tersebut akan dilakukan ritual adat yaitu}


dalam istilah masyarakat Mamasa disebut dipa'arrangngi tangngana langi'. Ritual ini tujuannya adalah untuk memberikan pengakuan kepada anak yang dimaksud sekaligus pengembalian nama baik bagi keluarga besar ibu dari anak tersebut.

Ritual dipa'arrangi tangngana langi' hanya berlaku untuk masalah anak yang lahir diluar kawin atau anak luar nikah. Anak luar nikah atau anak luar kawin adalah seorang anak yang lahir dari ibu dan ayahnya tanpa melalui proses perkawinan yang sah (lihat: Bushar; 1997, Sugangga; 1994, Hadikusuma; 2003).

Dikalangan masyarakat Mamasa anak luar nikah yaitu mereka yang lahir dari perkawinan tidak sah karena kedua orang tuanya tidak terikat dengan ikatan suami dan istri. Kondisi ini bisa terjadi pada seorang anak gadis sebagai orang tua anak tersebut tetapi laki-laki yang menghamilinya terikat perkawinan dengan istrinya yang sah atau kedua orang tua dari anak tersebut terikat dengan perkawinan yang sah misalnya ibu dengan suaminya yang sah dan ayah dengan istrinya yang sah dan atau juga ibu dari anak tersebut terikat dengan ikatan suami istri dengan suaminya yang sah tetapi laki-lakinya masih bujang.

Kondisi demikian dalam tradisi masyarakat adat Mamasa harus dinikahkan secara adat melalui ritual tersebut diatas. Alasannya adalah bahwa kedua orang tua anak tersebut tidak dapat dinikahkan yang pernikahan adatnya mengikatnya menjadi suami atau istri. Sebatas yang bisa dilakukan adalah supaya anak yang lahir diluar nikah tersebut mempunyai ayah yang sah dan diakui serta untuk mengembalika nama baik bagi keluarga ibunya yang dianggap tercemar keburukannya.

Dalam prosesi dipa'arrangi tangngana langi' tersebut pihak laki-laki sebagai ayah dari anak yang lahir tersebut diwakli oleh kerabat keluarganya mendatangi pihak keluarag ibu dari anak tersebut. Mereka datang untuk menyampaikan bahwa anak yang dimaksud ketika sudah lahir memiliki ayah dan ayahnya inilah adalah ayah kandung dari anak tersebut. Dalam ritual tersebut perwakilan ayah dari anak tersebut yang hadir semuanya adalah laki-laki dan tidak ada perempuan sama sekali.

Lembaga adat yang hadir sebagai fasilitator dan penengah mengantar pembicaraan yang selanjutnya member kesempatan kepada perwakilan keluarga dari pihak ayah dari anak tersebut untuk menyampaikan maksud kedatangannya. Dan setelah maksud tersebut telah tersampaikan maka selanjutnya pihak lembaga adat yang hadir member kesempatan kepada pihak keluarga perempuan untuk memberikan tanggapan atas maksud kedatangan dari pihak perwakilan ayah dari anak tersebut.

Biasanya pernyataan yang disampaikan oleh pihak yang mewakili keluarga perempuan menyampaikan ungkapan terimakasih karena mereka telah dipulihkan nama baik keluarganya. Dalam istilah mereka diangkat dari tangnga maririnna litak atau diangkat langngan pongka-pongka barana' secara harafiah berarti diangkat keatas puncak pohon beringin.

Karena anak yang akan lahir tersebut sudah sah mempunyai ibu dan ayah kandung maka lembaga adat mempersyaratkan kepada pihak laki-laki sebagai ayah dari anak tersebut dipertanggungkan untuk bertanggungjawab atas seluruh nafkah bagi anak tersebut. Biayah untuk pertumbuhan, pendidikan dll, semuanya merupaka tanggungjawab dari ayah anak tersebut sebagai seorang bapak didalam keluarga. Besaran biaya yang dipertaggugkan sesuai dengan kemampuan dari ayah anak tersebut.

Pada posisi ini terlihat bahwa ayah dari anak yang lahir diluar nikah tersebut setelah ritual perkawinan adat tersebut selesai dilakukan sudah memiliki hubungan perdata dengan ayah biologisnya. Berdasarkan UU Perkawinan dimana perkawinan yang sah secara tidak langsung istri dan anak yang dilahirkannya memiliki hubungan keperdataan dengan dirinya.

Setelah semua keluarga yang hadir merasa sudah dipulihkan nama baiknya atas kejadian tersebut maka selanjutnya adalah kedua belah pihak yang difasilitasi oleh lembaga adat membicarakan biaya yang digunakan selama ritual tersebut dilakukan. Biasanya pihak keluarga perempuan sebelumnya telah mengambil secara sepihak kebutuhan yang digunakan selama ritual tersebut berlangsung. Pihak laki-laki tidak ada alasan untuk tidak memenuhi segala biaya yang dibutuhkan tersebut berapapun besarannya.

Jika dicermati secara sepihak besaran biaya yang dikeluarkan oleh ayah anak tersebut sebagai pelaku tidaklah sebanding dengan rasa malu dan bahkan masa depan dari perempuan sebagai ibu dari anak tersebut. Tidak ada sanksi yang cukup berat sehingga dianggap tidak setimpal dengan perbuatan yang dilakukannya.

\section{Dampak Sosial Perkawinan terhadap Anak diluar Nikah}

Perkawinan adat Mamasa untuk anak yang lahir diluar nikah sangat membantu masyarakat adat Mamasa dalam menyeleseikan masalah yang biasanya berhubungan dengan nama baik keluarga tersebut. Selain itu bagian dari perlindungan kepada anak dimana perkawinan adat akan secara langsung melahirkan hubungan keperdataan dengan ayah kandungnya. Hal tersebut adalah bagian dari upaya untuk memberikan perlindungan kepada anak tersebut (lihat: Witanto 2012).

Beberapa dampak sosial yang ditimbulkan dengan adanya perkawinan adat yang memberikan pengakuan kepada anak yang lahir diluar nikah tersebut. Dengan adanya ritual perkawinan adat tersebut secara tidak langsung anak yang lahir diluar nikah tersebut telah sah dan diakui memilki ibu dan ayah kandung yang bertanggungjawab atas kelahirannya.

Perjanjian perikatan tersebut dibuat dan disepakati antara kedua keluarga yaitu pihak ibu da pihak ayah dari anak tersebut bersama dengan lembaga adat sebagai fasilitator dalam ritual perkawinan tersebut. Hasil kespakatan tersebut wajib hukumnya dilakukan, hanya saja karena pembuatan perikatannya tidak dalam bentuk surat yang ditandatangani maka tentu tidak dapat berakibat hak-hak secara hukum. 
Kegiatan ritual perkawinan adat ini untuk anak yang lahir diluar nikah juga sangat membantu bagi keluarga korban untuk memulihkan nama baik keluarganya sekalipun belum seutuhnya. Paling tidak dalam istilah mereka dipalangke langngan pangka-pangka barana' yang artinya diangkat kembali martabatnya. Dalam tradisi masyarakat adat Mamasa jika prosesi ritual tersebut tidak dilakukan karena laki-laki yang bersangkutan sebagai pelaku tidak bersedia bertangungjawab dianggap adalah suatu penghinaan bagi rumpun keluarganya yang setimpal dengan pertumpahan darah yang dalam istilah mereka disebut lemposan ulu.

Hanya saja tentu ada hal buruk yang dapat menjadi dampak negativ dengan adanya perkawinan adat anak diluar nikah tersebut. Ada persepsi yang kemudian muncul didalam masyarakat dimana perkawinan diluar nikah yang kemudian melahirkan anak diluar nikah tidak lagi dianggap suatu masalah bagi sebagian orang. Karena kalaupun ada terjadi masalah seperti itu, sanksi adat yang diberikan sangat kecil sehingga tidak memberi efek jerah. Bisa dibayangkan pelaku sebagai ayah anak yang lahir diluar nikah tersebut ketika perkawinan adat tersebut dilakukan hanya dipertanggungkan biaya ritual dan biaya pertumbuhan anak ketika sudah lahir. Pelaku tidak harus menikahi ibu dari anak tersebut bahkan tidak perlu diberi denda adat seperti yang dilakukan kepada kejahatan lain didalam wilayah keadatan Mamasa.

Sebagai contoh masalah adat yang diberi sanksi adat yang member efek jerah, misalnya ada dua orang yang ingin menikah. Pada saat pelamaran dilakukan maka kedua pasangan yang akan menikah tersebut telah menjadwalkan perkawinannya yang diputusakan dalam musyawarah kedua keluarga. Sebelum tiba waktu perkawinan yang telah ditetapkan tersebut, kemudian salah satu dari mereka mengundurkan diri dan tidak lagi bersedia melanjutkan perkawinan tersebut. Maka sanksi adat yang diberikan kepada yang mengundurkan diri adalah satu ekor kerbau yang besar dan jenisnya tergantung dari siapa yang akan diberikan. Dalam konteks inilah urgensi hukum adat yang direpresentasi melalui lembaga adat menunjukkan perannya (Bahri, et. al , 2017a; Bahri, et. al , 2017b).

\section{KESIMPULAN DAN SARAN}

Kesimpulan hasil penelitian ini bahwa sistem administrasi kependudukan anak luar nikah yang dilakukan oleh Dukcapil Mamasa selama dalam rangka pembuatan akta lahirnya dibuat dalam tiga jenis akta lahir. Kedudukan lembaga adat dalam pembuatan akta lahir anak diluar nikah selama ini belum dilakukan sebagai mana semestinya sesuai dengan yang diatur di dalam Perda Nomor 5 Tahun 2017. Mekanisme perkawinan adat Mamasa untuk anak diluar nikah dilakukan melalui sebuah ritual adat sebagai suatu tradisi adat yang dalam istilah masyarakat adat Mamasa disebut dengan istilah dipa'arrangi tangngana langi yang berarti diangkat kembali martabatnya. Dampak sosial perkawinan adat Mamasa terhadap anak diluar nikah adalah memeberikan pengakuan kepada kedudukan seorang anak dalam keluarga dan lingkungan sosialnya.

\section{DAFTAR PUSTAKA}

A. Pitlo, 1979, "Hukum Waris Menurut UndangUndang Hukum Perdata Belanda", PT. Intermasa, Jakarta.

Achyar, I. F., Juharni, J., \& Nurkaidah, N. (2019). Kualitas Pelayanan Dalam Sistem Penerbitan E-Ktp Pada Dinas Kependudukan Dan Pencatatan Sipil Kabupaten Maros. Jurnal Paradigma Administrasi Negara, 1(1), 27-31.

Andreae, S.J. 1951. Fockema. Rechtsgeleerd Handwoordenbook, Tweede Druk. J.B. Wolter Uitgeversmaatshaappij N.V. Groningen

Bahri, Syamsul, Natsir Tompo, Harifuddin Halim, Rasyidah Zainuddin. (2017a). Lembaga Adat To A'pa dan Urgensinya Bagi Masyarakat di Desa Labuku Kecamatan Maiwa Kabupaten Enrekang. Proceeding of CMR 2016 International Conference of Multidisciplinary Research "Earthing Knowledge Strengthening Connectivity" Faculty of Social and Political Science Hasanuddin University.

Bahri, Syamsul, Rasyidah Zainuddin, Harifuddin Halim. (2017b). Indigenous Institution and Local Community (Study of Tau Appa in the Maiwa Subdistrict). The Social Science 12(10): 1755-1758.

Bushar, Muhammad. 1997.Asas-Asas Hukum Adat. Jakarta: PT. Pradnya Paramita.

Gultom, Maidin. 2014. Perlindungan Hukum Terhadap Anak dan Perempuan, Bandung: PT. Reflika Aditama.

Hadikusuma, Hilman. 2003. Pengantar Hukum Adat Indonesia. CV Mandar Maju: Bandung.

IGN. Sugangga, 1994, "Pengantar Hukum Adat", Badan Penerbit Universitas Diponegoro, Semarang

J. Satrio, 2001, Hukum Perikatan,Perikatan Yang Lahir Dari Perjanjian Buku I, PT.Citra Aditya Bakti, Bandung

Napitupulu, Paiman. 2007. Pelayanan Publik dan Customer Satisfaction, Bandung: PT. Alumni.

Putusan Mahkamah Konstitusi No.46/PUU-VII/2010.

Peraturan Daerah Nomor 5 Tahun 2017 tentang Pemberdayaan dan Pengembangan Lembaga Adat

Sangkala. 2006. Intellectual Capital Manajemen, Jakarta: YAPENSI.

Subekti dan R. Tjitrosoedibio. 1980. Kamus Hukum, Jakarta: Pradnya Paramita.

Sudikno, Mertokusuma. 2002. Hukum Acara Perdata Indonesia, Yogyakarta: Liberty.

Sudiyat, Imam. 2000. Hukum Adat (Sketsa Asas) Cetakan Ke-4, Liberty Yogyakarta, Yogyakarta.

Witanto, D.Y. 2012. Hukum Keluarga: Hak Kedudukan Anak Luar kawin, Jakarta: Prestasi Pustaka. 